\title{
Corporate Financial Policy and the VAlue of Cash under UnCERTAinty
}

\author{
Christopher F Baum* \\ Boston College and DIW Berlin \\ Atreya Chakraborty \\ University of Massachusetts-Boston \\ Boyan Liu \\ Beihang University
}

\begin{abstract}
In this paper we provide evidence on how firm-specific and macroeconomic uncertainty affects shareholders' valuation of a firm's cash holdings. This extends previous work on this issue by highlighting the importance of the source of uncertainty. Our findings indicate that increases in firm-specific risk generally increase the value of cash while increases in macroeconomic risk generally decrease the value of cash. These findings are robust to alternative definitions of the unexpected change in cash. We extend our analysis to financially constrained and unconstrained firms.

Keywords: cash holdings, marginal value of cash, macro uncertainty, idiosyncratic uncertainty, financial constraints. JEL: G32, G34, D81.

*This paper was completed during Boyan Liu's stay as a Visiting Scholar at Boston College, which was financially supported by National Natural Science Foundation of China, No. 70521001, and Research Fund of China Ministry of Education for Ph.D. Development, No. 20050006025. Christopher F Baum gratefully acknowledges financial support from the Fritz Thyssen Foundation. We are grateful to an anonymous reviewer for constructive suggestions. Corresponding author: Atreya Chakraborty, Department of Accounting and Finance, College of Management, University of Massachusetts-Boston, 100 Morrissey Blvd., Boston, MA 02125 USA, Tel: 617-287-7673, fax 617-287-7694, e-mail: atreya.chakraborty@umb.edu.
\end{abstract}




\title{
Corporate Financial Policy and the VAlue of CASH UNDER UNCERTAINTY
}

\begin{abstract}
In this paper we provide evidence on how firm-specific and macroeconomic uncertainty affects shareholders' valuation of a firm's cash holdings. This extends previous work on this issue by highlighting the importance of the source of uncertainty. Our findings indicate that increases in firm-specific risk generally increase the value of cash while increases in macroeconomic risk generally decrease the value of cash. These findings are robust to alternative definitions of the unexpected change in cash. We extend our analysis to financially constrained and unconstrained firms.

Keywords: cash holdings, marginal value of cash, macro uncertainty, idiosyncratic uncertainty, financial constraints. JEL: G32, G34, D81.

\section{Introduction}

Recent findings indicate that cash holdings of non-financial firms have dramatically increased. For example, Bates et al. (2009) report that the average cash-to-asset ratio for US industrial firms more than doubled between 1980 and 2006. Current disclosures points to a strengthening of this tend. Non-financial companies in the Standard \& Poor's 500-stock index were holding $\$ 1.12$ trillion in cash and short-term investments in their most recent financial statements, up $59 \%$ from $\$ 703$ billion in the third quarter of 2008 (Monga et al. (2011)). While coping with future uncertainty is the most common explanation for accumulating such reserves, investors who can diversify these risks are questioning the value of these historically high cash reserves
\end{abstract}


(Berman (2011)). Does an added dollar in cash reserves, even in uncertain times, increase firm value by one dollar? Does the valuation of cash reserves depend on the source of uncertainty faced by the firm? These are the primary questions we investigate in this paper.

From an analytical standpoint, there are both costs and benefits of firms' cash holdings. Agency theory points to the costs arising from the "free cash flow problem" (Jensen (1986), Stulz (1990)). Internally generated funds allow managers to skirt the discipline imposed by the capital markets and utilize funds to undertake investments that may not maximize shareholder value (Opler et al. (1999), Blanchard et al. (1994)). An increase in the uncertainty facing the firm exacerbates these agency costs, as evaluating the expected return of an investment project becomes more difficult.

However, cash holdings can also be beneficial, as they allow a firm to avoid the direct transactions costs of debt or equity issue and the indirect cost of mispricing due to the information asymmetry costs associated with new issuance. These benefits could be substantial for firms that are credit constrained. More importantly, as increases in uncertainty are associated with higher informational asymmetries, one would expect the benefits of cash holdings to be even greater as the firm operates in a more uncertain environment. Faulkender and Wang (2006) and Pinkowitz and Williamson (2007) provide robust findings along these lines.

Empirical evidence also indicates that the source of uncertainty-firm-specific or macroeconomic uncertainty - also affects a firm's cash-to-asset ratio (Baum et al. (2008)). While they find that both sources of uncertainty unambiguously increase cash-to-asset ratios, their findings do not address the valuation of these cash reserves. Shareholders' valuation of additions to the firm's cash buffer in the face of liquidity may differ depending on the nature of uncertainty. For instance, a higher perceived level of macroeconomic risk increases all firms' value of their real option to invest in additional capital, and renders precautionary cash balances more costly. Conversely, 
greater idiosyncratic risk increases the firm's risk of bankruptcy. Shareholders may consider it prudent for managers to increase precautionary cash balances, and value the additional cash more highly in this context. This raises an interesting empirical question regarding the relationship between the source of uncertainty and the valuation of a firm's cash holdings.

Consistent with the findings of Faulkender and Wang (2006) and Pinkowitz and Williamson (2007), our estimates show that uncertainty will affect the marginal valuation of cash. The contribution of our study relative to the existing literature is that we draw a crucial distinction: the source and nature of uncertainty matters. We find that the cost of holding extra cash increases, relative to the benefits, when a firm faces a more uncertain macroeconomic environment. Specifically, a marginal dollar of cash is valued at about $\$ 0.86$ at the $10^{\text {th }}$ percentile of macroeconomic uncertainty, but it is worth just over $\$ 0.78$ at the $90^{\text {th }}$ percentile. However, greater firm-level uncertainty will increase the marginal valuation of cash from $\$ 0.82$ to almost $\$ 0.86$.

An additional contribution of our analysis is that we provide greater insight into the effects of uncertainty on firm behavior by allowing for its continuous variation. Pinkowitz and Williamson (2007) found that the marginal value of cash is greater in a firm with more volatile capital investment opportunities, or a more volatile R\&D program. Their comparisons, however, are based on categorizing firms into leastvolatile and most-volatile groups. Our approach is more general as it captures the time-varying nature of volatility, or uncertainty, over time.

To address these issues, we first review the relevant literature. In Section 3, we modify the model analyzed in Faulkender and Wang (2006) to take account of the effects of uncertainty. Our empirical findings are presented in Section 4 and Section 5 offers concluding remarks. 


\section{The effects of uncertainty on the costs and ben- efits of cash holdings}

It is well known that some non-financial corporations hold significant amounts of cash equaling a considerable fraction of their annual turnover: in many cases, exceeding their indebtedness. ${ }^{1}$ An increasingly uncertain business environment, primarily due to globalization and technological change, is often cited as the primary reason for this spike in cash holdings. There is an extensive literature on the connection between uncertainty faced by the firm and the benefits of corporate cash holdings, going back to Keynes (1936). A firm operating in an uncertain environment, he suggests, may benefit from accumulation of cash due to both the ability to deal with unanticipated contingencies (the precautionary motive) and access profit-making opportunities (the speculative motive).

Recent empirical findings support for such motives. ${ }^{2}$ Pinkowitz and Williamson (2007), for example, find that the value of cash is significantly greater for firms with high volatility of cash flows and capital expenditures. They note "A company's cash holdings effectively provide it with the means of exercising a growth option, if you will, and that option is more valuable when the volatility of the underlying business and investment program is greater." (p. 78)

When evaluating the impact of uncertainty on managers' decision-making, prior research has demonstrated the importance of distinguishing the type of uncertainty faced by the firm. Uncertainty may occur at the macroeconomic, sector or industry level, and may have similar effects on a firm and its competitors, however broadly defined. On the other hand, uncertainty may be idiosyncratic to the firm, specific to its particular position in the markets for its inputs and outputs. In this context, we expect that the type of uncertainty clouding managers' decisions is relevant, and may have quite different consequences for their behavior.

Baum et al. (2008) provide a theoretical model that highlight how macroeconomic 
or firm-specific uncertainty may affect firms' liquidity: specifically, their cash-to-asset ratios. This model is motivated by a two-period cash buffer-stock model in which managers choose a level of liquidity to maximize the expected value of the firm. Empirical findings indicate that both firm-specific and macroeconomic uncertainty will cause managers to increase their cash-to-asset ratios. However, their work does not focus directly on the marginal value of cash.

Cash holdings may also lower borrowing costs in uncertain times when due to the unpredictability of firms' investment opportunities, the cost of accessing external funding may be substantial. Focusing on macroeconomic shocks, Cummins and Nyman (2004) demonstrate that firms facing a fixed cost of acquiring external finance in an uncertain environment will hold cash as a buffer against the need to borrow in later periods. Graham and Harvey (2001b) emphasize the importance of financial flexibility (having enough internal financing sources) when managers make financing decisions to avoid curtailing their business activities in response to macroeconomic shocks.

Managers' access to considerable amounts of cash can also be costly to the shareholders. As mentioned earlier there is good evidence that the agency cost of free cash flows can be substantial. Opler et al. (1999) find that companies with excess cash spend more on acquisitions that are not necessarily value increasing. Richardson (2006) reports that for non-financial firms during 1988-2002, the average firm over-invests 20 percent of its available free cash flows. Li (2004) also documents lower operating performance following increases in free cash flow. As informational asymmetry between managers and shareholders exacerbates agency costs, such costs are expected to be even larger in periods of heightened uncertainty. Equity holders also bear a tax-related cost of cash holdings as interest earned on corporate cash reserves is taxed at a higher rate than interest earned by individuals.

Myers and Rajan (1998) point out how the cost of credit to a cash-rich firm may increase if creditors view the added flexibility in investment that comes from holding 
cash. Haubrich and dos Santos (1997) provide the logic underlying this thinking in the following (albeit colorful) way: “...consider which firm's managers would have an easier time expropriating the company's assets and running off to Tahiti-one whose assets consisted of T-bills, or one whose only asset was a marble quarry? Now take the analysis back one step: Who would have an easier time raising money from suspicious lenders: a company whose asset was a quarry, or one that proposed keeping the money as cash?" (p. 3)

Extending the intuition the flexibility provided by cash is valuable, recent findings from Simutin (2010) find that excess cash holdings proxy for risky growth options. More importantly, he finds that these growth options due to cash holding are not equally valuable in all market states. Firms with larger cash holdings outperform their peers in times of market slowdowns but outperform their peers during expansions. Such findings hint at how real options embedded in firms' cash holdings can affect their value due to macroeconomic risks.

Similarly expansions and contractions, often triggered by macroeconomic events, may also promote strategic use of firms' cash holdings. In some circumstances, cash in hand may allow a firm to invest in opportunities that preempt their rivals in the market. In this context of predatory strategies, Chi and $\mathrm{Su}$ (2016) find that value of cash holdings is mostly driven by firms' facing greater investment opportunities or more binding financial constraints.

From this evidence, it is apparent that uncertainty should affect firms' cash holding behavior. However, given that there are costs and benefits from holding cash that may vary over time, it is not possible a priori to predict how an extra dollar of cash will be valued. The source of uncertainty may be important; as we argue above, shareholders may view greater uncertainty about the course of the macroeconomy quite differently than greater uncertainty about a particular firm's prospects. Ultimately, the effect of uncertainty on the marginal valuation of a firm's cash is an empirical question, which we seek to answer. 


\section{Modeling corporate financial policy}

We test the hypothesis that the marginal effect of cash holdings on excess stock returns is sensitive to uncertainty. To compute this marginal effect, we adopt and extend the approach of Faulkender and Wang (2006) to our more elaborate model. Consider the baseline regression model of their equation (9):

$$
\begin{aligned}
r_{i, t}-R_{i, t}^{B}=\quad & \gamma_{0}+\gamma_{1} \frac{\Delta C_{i, t}}{M_{i, t-1}}+\gamma_{2} \frac{\Delta E_{i, t}}{M_{i, t-1}}+\gamma_{3} \frac{\Delta N A_{i, t}}{M_{i, t-1}}+\gamma_{4} \frac{\Delta R D_{i, t}}{M_{i, t-1}} \\
& +\gamma_{5} \frac{\Delta I_{i, t}}{M_{i, t-1}}+\gamma_{6} \frac{\Delta D_{i, t}}{M_{i, t-1}}+\gamma_{7} \frac{C_{i, t-1}}{M_{i, t-1}}+\gamma_{8} L_{i, t}+\gamma_{9} \frac{N F_{i, t}}{M_{i, t-1}} \\
& +\gamma_{10} \frac{C_{i, t-1}}{M_{i, t-1}} \times \frac{\Delta C_{i, t}}{M_{i, t-1}}+\gamma_{11} L_{i, t} \times \frac{\Delta C_{i, t}}{M_{i, t-1}}+\epsilon_{i, t}
\end{aligned}
$$

In their approach, excess stock returns are regressed on the unexpected change in cash holdings $\left(\Delta C_{i, t}\right)$, scaled by the prior period's market value of the firm $\left(M_{i, t-1}\right)$ and other controls. The unexpected change in cash is also introduced in interacted form with the prior period's level of cash $\left(C_{i, t-1}\right)$, scaled by market value, and with market leverage $\left(L_{i, t}\right)$. The authors consider four different measures of $\Delta C_{i, t}$; we consider two of those measures in this study.

We augment this model with two forms of uncertainty facing the firm, macroeconomic uncertainty $\left(\sigma_{M}^{2}\right)$ and firm-specific uncertainty $\left(\sigma_{f}^{2}\right)$, by adding proxies for these two forms of time-varying uncertainty to the regression: in their levels and interacted with the scaled measures of $\Delta C_{i, t}$. Our augmented equation becomes:

$$
\begin{aligned}
r_{i, t}-R_{i, t}^{B}= & \gamma_{0}+\gamma_{1} \frac{\Delta C_{i, t}}{M_{i, t-1}}+\gamma_{2} \frac{\Delta E_{i, t}}{M_{i, t-1}}+\gamma_{3} \frac{\Delta N A_{i, t}}{M_{i, t-1}}+\gamma_{4} \frac{\Delta R D_{i, t}}{M_{i, t-1}} \\
& +\gamma_{5} \frac{\Delta I_{i, t}}{M_{i, t-1}}+\gamma_{6} \frac{\Delta D_{i, t}}{M_{i, t-1}}+\gamma_{7} \frac{C_{i, t-1}}{M_{i, t-1}}+\gamma_{8} L_{i, t}+\gamma_{9} \frac{N F_{i, t}}{M_{i, t-1}}
\end{aligned}
$$




$$
\begin{aligned}
& +\gamma_{10} \frac{C_{i, t-1}}{M_{i, t-1}} \times \frac{\Delta C_{i, t}}{M_{i, t-1}}+\gamma_{11} L_{i, t} \times \frac{\Delta C_{i, t}}{M_{i, t-1}}+\gamma_{12} \sigma_{M, t}^{2} \\
& +\gamma_{13} \sigma_{f, t}^{2}+\gamma_{14} \sigma_{M, t}^{2} \times \frac{\Delta C_{i, t}}{M_{i, t-1}}+\gamma_{15} \sigma_{f, t}^{2} \times \frac{\Delta C_{i, t}}{M_{i, t-1}}+\nu_{i}+\epsilon_{i, t}
\end{aligned}
$$

In this specification, we include a firm fixed effect, $\nu_{i}$. In our estimated models, a test for fixed effects always rejects the null hypothesis that they may be omitted from the equation, indicating that firm-specific unobserved heterogeneity will lead to bias and inconsistency in pooled OLS results. ${ }^{3}$

Our hypothesis regarding the importance of uncertainty for cash holdings behavior will receive support from the data if the marginal effect of scaled $\Delta C_{i, t}$ varies meaningfully with one or both measures of uncertainty. Significant values of coefficients $\gamma_{12}, \gamma_{13}$ would indicate that the uncertainty measures are relevant omitted variables in the prior specification. Significant values of coefficients $\gamma_{14}, \gamma_{15}$ would indicate that variations in uncertainty moderate the effects of changes in cash on the dependent variable. We can use the above coefficients to estimate how the market changes its valuation of the marginal dollar as each measure of uncertainty changes. For instance, the change in the marginal valuation of cash in Equation (1) involves only $\left(\gamma_{1}+\gamma_{10} C / M+\gamma_{11} L\right)$. The addition of uncertainty factors in Equation (2) imply that the terms $\left(\gamma_{14} \sigma_{M}^{2}+\gamma_{15} \sigma_{f}^{2}\right)$ must be added to the expression, evaluated at some positive level of uncertainty. ${ }^{4}$ These calculations have important implications if the market views that the costs and the benefits of holding cash are dependent on the degree of uncertainty about the macroeconomy and about the firm. For example, the net effect of both measures of uncertainty on the marginal value of cash may be quite small, yet each source of uncertainty may have a significant (and possibly opposing) effect on the value of cash holdings.

A challenge to any study considering the effects of uncertainty on firms' behavior is the construction of an appropriate proxy for each type of uncertainty. The next subsections describe our strategy in generating proxies for macroeconomic and firm- 
specific uncertainty, respectively.

\subsection{Identifying macroeconomic uncertainty}

In our investigation, as in Driver et al. (2005), Byrne and Davis (2002) and Baum et al. (2008) we use a GARCH model to proxy for macroeconomic uncertainty. We believe that this approach is more appropriate compared to alternatives such as proxies obtained from moving standard deviations of the macroeconomic series (e.g., Ghosal and Loungani (2000)) or survey-based measures based on the dispersion of forecasts (e.g., Graham and Harvey (2001a), Schmukler et al. (1999)).

We consider a volatility measure derived from changes in the consumer price index (CPI) as a proxy for the macro-level uncertainty that firms face in their financial and production decisions. We build a generalized ARCH $(\operatorname{GARCH}(1,1))$ model for CPI inflation where the mean equation is an autoregression over 1962m3-2006m12, as reported in Table 1. We allow the error term in this equation to be distributed as Student $t$, and estimate the appropriate degrees of freedom for the process. The conditional variance derived from this GARCH model is averaged to the annual frequency and then employed in the analysis as our measure of macroeconomic uncertainty.

As a robustness check, we also used the index of leading indicators produced by the Conference Board to construct a second proxy for macroeconomic uncertainty. The change in the log of the index is modeled as an autoregression in a $\operatorname{GARCH}(1,2)$ framework. We reestimated the models described below and received very similar qualitative findings. For brevity, we do not report those results in the paper; they are available on request to the authors. ${ }^{5}$

\subsection{Identifying firm-specific uncertainty}

One can employ different proxies to capture firm-specific risk. For instance, Bo and Lensink (2005) use three measures: stock price volatility, estimated as the difference between the highest and the lowest stock price normalized by the lowest price; 
volatility of sales measured by the coefficient of variation of sales over a seven-year window; and the volatility of number of employees estimated similarly to volatility of sales. Bo (2002) employs a slightly different approach, setting up the forecasting $\mathrm{AR}(1)$ equation for the underlying uncertainty variable driven by sales and interest rates. The unpredictable part of the fluctuations, the estimated residuals, are obtained from that equation and their three-year moving average standard deviation is computed. Kalckreuth (2000) uses cost and sales uncertainty measures, regressing operating costs on sales. The three-month aggregated orthogonal residuals from that regression are used as uncertainty measures.

In this study, we proxy firm-level uncertainty by computing the standard deviation of the firm's previous three years' cash flow/assets ratio, adjusted for the median ratio in its industry, as defined by the firm's two-digit SIC. ${ }^{1}$ We have also considered this measure over a five-year window, and the sales/assets ratio over both three-year and five-year horizons. Our qualitative findings are unchanged using these alternative measures. As the three-year window is the most parsimonious in terms of the data, we report results based on that measure.

As an alternative measure, we compute a proxy for firm-level uncertainty along the lines of Kalckreuth (2000) by regressing operating income on sales, with firm and year fixed effects. ${ }^{2}$ The residuals from this regression are aggregated over a three-year moving sum to produce the uncertainty measure.

To ascertain that the firm-level measures captured by these methods are distinct from that used to proxy macroeconomic uncertainty, we compute their pairwise correlations. The cash flow proxy and macroeconomic uncertainty proxy are correlated -0.0568 , while the operating income/sales proxy and macroeconomic uncertainty proxy are correlated 0.0011. Therefore, the macroeconomic and idiosyncratic measures of uncertainty are essentially orthogonal.

\footnotetext{
${ }^{1}$ We are grateful to an anonymous reviewer for suggesting this adjustment.

${ }^{2}$ We thank an anonymous reviewer for this suggestion.
} 


\subsection{Data}

For the empirical investigation we work with Standard \& Poor's Annual Industrial COMPUSTAT database of U.S. firms. The initial database includes 210,632 firmyear characteristics over 1971-2006. The firms are classified by two-digit Standard Industrial Classification (SIC). We exclude corporations with two-digit SIC codes of 49 (regulated industries) and 60-69 (financial industries).

In order to construct firm-specific variables we utilize COMPUSTAT data items Cash and Short-term Investment (data1), Total Assets (data6), Interest expense (data15), Common dividends (data21) and Research and Development expense (data46). Following Faulkender and Wang (2006), net assets are defined as total assets minus cash holdings. Earnings are the sum of earnings before extraordinary items (data18) plus interest (data15), deferred tax credits (data50), and investment tax credits (data51). Leverage is calculated as total debt (data9+data34) over the sum

of total debt and the market value of equity. Net financing is defined as total equity issuance (data108) minus repurchases (data115) plus debt issuance (data111) minus debt redemption (data114). We use the 25 Fama and French (1998) portfolios defined for firm size and book-to-market ratios as benchmark portfolios to construct the firm's excess stock return, $\left(r_{i, t}-R_{i, t}^{B}\right)$.

Descriptive statistics for the annual means of the variables used in this study as well as the proxies for uncertainty are presented in Table 2.

\section{Empirical findings}

Our empirical investigation begins with models estimated over the full sample that incorporate the unexpected change in cash holdings under two alternative definitions of that quantity. In column [1] of Table 3, we consider that market participants' expectations of the change in cash holdings matched that realization: $\triangle C 1$, a specification generally comparable to that of Faulkender and Wang (2006), Table II (p. 
1973). Our alternative definition, $\Delta C 3$ in their notation, considers the expected change in cash to be the average change in the benchmark portfolio (defined by firm size and market-to-book ratio) over the fiscal year, and is used in the model presented in column [3]. In these specifications the marginal value of a dollar of cash for the median firm is $\$ 0.89-0.90$, as presented at the foot of Table 3, along with its estimated standard error. This is consistent with the earlier intuition that the market value of firms' cash holdings incorporates the extra taxes a firm pays for this buffer stock of cash.

Column [2] expands our baseline specification. We introduce measures of macroeconomic and firm-specific uncertainty in the model, as well as their interactions with a scaled measure of the unexpected changes in cash holdings. In column [4], we similarly include both measures of uncertainty and their interactions in our alternate baseline model. In all of our specifications, both measures of uncertainty affect the value of cash in a statistically significant way, but with opposite-signed effects. ${ }^{6}$ The marginal value of cash increases with a rise in firm-specific risk but falls with an increase in macroeconomic risk. Interestingly, in both of these uncertainty-augmented specifications the marginal value of a dollar of cash for the median firm is $\$ 0.83-$ 0.85, as shown at the foot of the table. This small decline in the marginal value of cash when uncertainty factors are accounted for is somewhat illusory. The different sources of uncertainty in fact have significant effects on how the market values a firm's cash holdings. However, given that these effects work against each other, their net impact on the median firm is quite modest.

However, when we fit the model using our alternative proxy for firm-level uncertainty, based on the unexpected change in operating income vs. sales, we do not find significant variation in the value of cash over percentiles of this measure. Although the effect of firm-level uncertainty is quite precisely estimated, variations in the measure have little effect on the value of cash. For brevity, we do not tabulate these findings. 
In Figure 1 we depict the impact of each measure of uncertainty on the marginal value of cash. This figure shows that the sensitivity of the value of cash to macroeconomic uncertainty is quite significant at higher levels of uncertainty. While the market would value a marginal dollar of cash at about $\$ 0.86$ when there is very low uncertainty, a marginal dollar of cash is worth just over $\$ 0.78(\$ 0.72)$ at the $90^{\text {th }}\left(95^{t h}\right)$ percentile of macroeconomic uncertainty. The cost of holding extra cash increases, relative to the benefits, as a firm faces a more uncertain macroeconomic environment with higher real option values. This tradeoff is reversed when a firm faces higher firm-specific risk in terms of cash-flow volatility. That effect however is milder, with variation between $\$ 0.82$ for low uncertainty and almost $\$ 0.88$ for high uncertainty. Figure 2 presents similar evidence for the alternative measure of the change in cash holdings, $\Delta C 3$.

The findings above - in particular the statistically significant impact of macroeconomic shocks - are present even after controlling for the Fama-French factors, and are robust to alternative definitions of the proxy for macroeconomic uncertainty. These findings are in line with the extensive literature that considers the role of macroeconomic uncertainty on a firm's capital structure and liquidity decisions: fundamental factors that play a role in shareholders' evaluations of the value of the firm. Carruth et al. (2000) provide a good survey of the literature on this issue. For example, Leahy and Whited (1996) report a negative relationship between investment and uncertainty that primarily operates through Tobin's $q$. They do not find an effect working through a risk-based capital asset pricing model. Also, reporting on the impact of macro shocks on investment decisions, Beaudry et al. (2001) find that the "conditional variance of inflation is inversely related to the cross-sectional variance of the investment rate, calculated for the entire manufacturing sector, or within more narrowly defined industries." (p. 661) 


\subsection{Estimation for financially constrained vs. unconstrained firms}

Our model predicts that shareholders will place a larger value on a dollar of cash held by a firm facing financial constraints. We consider the dividend payout ratio as a plausible proxy for the existence of financial constraints. Firms with high payout ratios are considered less likely to face financial constraints, and are defined as unconstrained. In Table 4, we present estimates for subsamples defined by the payout measure of financial constraints ${ }^{3}$ for the original measure of the change in cash holdings, $\Delta C 1$. Table 5 reports results from an identical exercise with the alternative measure of the change in cash holdings, $\Delta C 3$.

As a robustness check, following Almeida and Campello (2007), we defined subsamples based on firm size, using the lowest (highest) three deciles of sales each year to represent financially constrained (unconstrained) firms. ${ }^{4}$ Results for the firm sizebased classification with the original measure of the change in cash holdings, $\Delta C 1$, are presented in Tables 6 and 7 .

The model's predictions are borne out for both measures of cash holdings. The estimates from Column [1] and Column [3] in both Tables 4 and 5 indicate the marginal value of a dollar of cash is considerably higher for the constrained (low payout) firm. The value of the marginal dollar increases from approximately $\$ 0.63$ for the unconstrained (high payout) firms to almost $\$ 0.76$ for constrained firms.

Following our earlier strategy, Column [2] and Column [4] in Table 4 expand our constrained and unconstrained estimates to include the uncertainty measures, both in levels and interacted with a scaled measure of the unexpected changes in cash holdings. An identical exercise is performed in Column [2] and Column [4] in Table 5 using the $\Delta C 3$ measure of the change in cash holdings. Our results indicate

\footnotetext{
${ }^{3}$ Following Almeida et al. (2004), we define subsamples as the lowest $30 \%$ and highest $30 \%$ of the distribution of the variable.

${ }^{4}$ We thank an anonymous reviewer for this suggestion.
} 
that both measures of uncertainty affect the marginal value of cash, even though the individual coefficients are not always statistically significant. However, the effect of uncertainty depends upon the linear combination of its coefficients, evaluated at a particular level of $\Delta C$. Thus, to consider the importance of uncertainty to the marginal value of cash, we must calculate its impact on the marginal value of cash at various levels of uncertainty.

To illustrate this point (see Figures 3 and 4), we decompose the impact of each measure of uncertainty on the value of cash for constrained and unconstrained subsamples as reported in Table 4. These figures show that for the constrained (lowpayout) firms, the effect of both types of uncertainty on the value of cash is qualitatively similar (and generally stronger) to the earlier results from the full sample. Higher levels of macroeconomic uncertainty decrease the value of marginal cash while higher levels of firm-specific uncertainty make marginal cash more valuable.

For the unconstrained firms, however, both measures of uncertainty increase the value of cash. Clearly the benefits of extra cash appear to swamp the costs when either measure of uncertainty increases. Extra cash for a high-payout firm may be all more valuable because it allows them to honor their pre-commitment to a steady dividend even in uncertain environments. There is strong evidence that unexpected change in payouts have a significant effect on stock prices (Kothari and Shanken (1992)).

Results for the subsamples by firm size are illustrated in Figures 5 and 6 for the alternative measures of the change in cash holdings. The results are broadly similar to those derived from the payout ratio.

In summary, our results show that macroeconomic uncertainty plays an important role in the relationship between the unexpected change in cash and excess equity returns for both constrained and unconstrained firms. Firm-specific uncertainty also plays an important role in that relationship, and interactions between firm-level uncertainty and unexpected changes in cash are generally significant. 


\section{Conclusions}

Our analysis considers how shareholders' evaluation of the marginal value of cash may be altered by the consideration of uncertainty facing the firm's managers. Our findings indicate that that the source of uncertainty-firm-specific versus macroeconomic risk-matters, as the two sources of risk may have quite different effects on shareholders' valuation of a firm's cash holdings. These new findings are robust to alternative definitions of the unexpected change in cash. Our measures of risk also extend earlier work on this issue such as Baum et al. (2008). We explicitly account for the time-varying nature of volatility (or uncertainty) over time rather than categorizing firms into more-volatile and less-volatile categories. This allows us to extend the original hypothesis. The impact of these innovations can be best seen in Figures 1 and 2, where the effect of each measure of uncertainty is plotted against the marginal value of cash. Such an analysis is simply not possible in the original Faulkender and Wang framework. 


\section{References}

Almeida, H. and Campello, M. (2007), 'Financial constraints, asset tangibility, and corporate investment', Review of Financial Studies 20(5), 1429-1460.

Almeida, H., Campello, M. and Weisbach, M. (2004), 'The cash flow sensitivity of cash', Journal of Finance 59(4), 1777-1804.

Bates, T. W., Kahle, K. M. and Stulz, R. M. (2009), 'Why do U.S. firms hold so much more cash than they used to?', Journal of Finance 64(5), 1985-2021.

Baum, C. F., Caglayan, M., Stephan, A. and Talavera, O. (2008), 'Uncertainty determinants of corporate liquidity', Economic Modelling 25, 833-849.

Beaudry, P., Caglayan, M. and Schiantarelli, F. (2001), 'Monetary instability, the predictability of prices and the allocation of investment: An empirical investigation using UK panel data', American Economic Review 91(3), 648-662.

Berman, D. (2011), 'Apple holders: Give us our cash! wall street journal, 18 January 2011 '

Blanchard, O. J., Lopez-de Silanes, F. and Shleifer, A. (1994), 'What do firms do with cash windfalls?', Journal of Financial Economics 36(3), 337-360.

Bo, H. (2002), 'Idiosyncratic uncertainty and firm investment', Australian Economic Papers 41(1), 1-14.

Bo, H. and Lensink, R. (2005), 'Is the investment-uncertainty relationship nonlinear? An empirical analysis for the Netherlands', Economica 72(286), 307-331.

Byrne, J. P. and Davis, E. P. (2002), Investment and uncertainty in the G7, Discussion papers, National Institute of Economic Research, London.

Carruth, A., Dickerson, A. and Henley, A. (2000), 'Econometric modelling of UK aggregate investment: The role of profits and uncertainty', Manchester School 68(3), 276-300.

Chi, J. D. and Su, X. (2016), 'Product market threats and the value of corporate cash holdings', Financial Management in press.

Cummins, J. G. and Nyman, I. (2004), 'Optimal investment with fixed financing costs', Finance Research Letters 1(4), 226-235. 
Driver, C., Temple, P. and Urga, G. (2005), 'Profitability, capacity, and uncertainty: A model of UK manufacturing investment', Oxford Economic Papers 57(1), 120141.

Fama, E. F. and French, K. R. (1998), 'Taxes, financing decisions, and firm value', Journal of Finance 53(3), 819-843.

Faulkender, M. and Wang, R. (2006), 'Corporate financial policy and the value of cash', Journal of Finance 61(4), 1957-1990.

Ghosal, V. and Loungani, P. (2000), 'The differential impact of uncertainty on investment in small and large business', The Review of Economics and Statistics 82, 338-349.

Graham, J. R. and Harvey, C. R. (2001a), Expectations of equity risk premia, volatility and asymmetry from a corporate finance perspective, NBER Working Papers 8678, National Bureau of Economic Research, Inc.

Graham, J. R. and Harvey, C. R. (2001b), 'The theory and practice of corporate finance: Evidence from the field', Journal of Financial Economics 60, 187-243.

Haubrich, J. G. and dos Santos, J. C. (1997), 'The dark side of liquidity', Federal Reserve Bank of Cleveland Economic Commentary (Sep 15).

Jensen, M. C. (1986), 'Agency costs of free cash flow, corporate finance, and takeovers', American Economic Review 76(2), 323-29.

Kalckreuth, U. (2000), Exploring the role of uncertainty for corporate investment decisions in Germany, Discussion Papers 5/00, Deutsche Bundesbank - Economic Research Centre.

Keynes, J. M. (1936), The general theory of employment, interest and money, London, Harcourt Brace.

Kothari, S. P. and Shanken, J. (1992), 'Stock return variation and expected dividends : A time-series and cross-sectional analysis', Journal of Financial Economics 31(2), 177-210.

Leahy, J. V. and Whited, T. M. (1996), 'The effect of uncertainty on investment: Some stylized facts', Journal of Money, Credit and Banking 28(1), 64-83.

Li, D. (2004), The implications of capital investments for future profitability and stock returns-An overinvestment perspective, Working paper series, University of California-Berkeley. 
Monga, V., Mattioli, D. and Chasan, E. (2011), 'In carnage, cash comforts. wall street journal, 11 August 2011.'.

Myers, S. C. and Rajan, R. G. (1998), 'The paradox of liquidity', Quarterly Journal of Economics 113(3), 733-771.

Opler, T., Pinkowitz, L., Stulz, R. and Williamson, R. (1999), 'The determinants and implications of corporate cash holdings', Journal of Financial Economics 52, 3-46.

Pinkowitz, L. and Williamson, R. (2007), 'What is the market value of a dollar of corporate cash?', Journal of Applied Corporate Finance 19(3), 74-81.

Richardson, S. (2006), 'Over-investment of free cash flow', Review of Accounting Studies 11, 159-189.

Schmukler, S., Mehrez, G. and Kaufmann, D. (1999), Predicting currency fluctuations and crises - do resident firms have an informational advantage?, Policy Research Working Paper Series 2259, The World Bank.

Simutin, M. (2010), 'Excess cash and stock returns', Financial Management 39(3), 1197-1222.

Stulz, R. M. (1990), 'Managerial discretion and optimal financing policies', Journal of Financial Economics 26(1), 3-27. 


\section{Cash measure: $\Delta \mathrm{C} 1$}
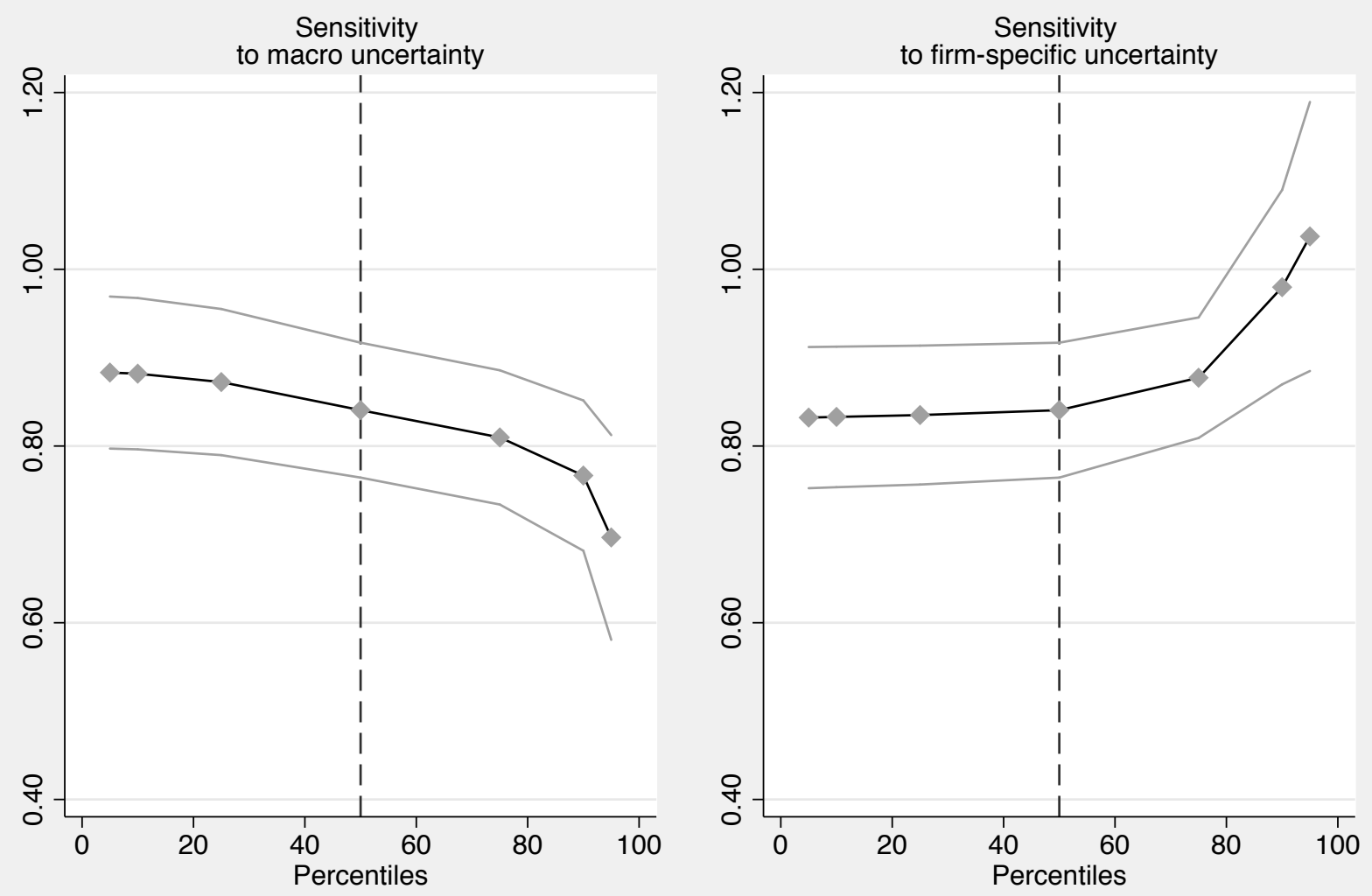

Figure 1: Sensitivity of marginal value of cash 


\section{Cash measure: $\Delta \mathrm{C} 3$}
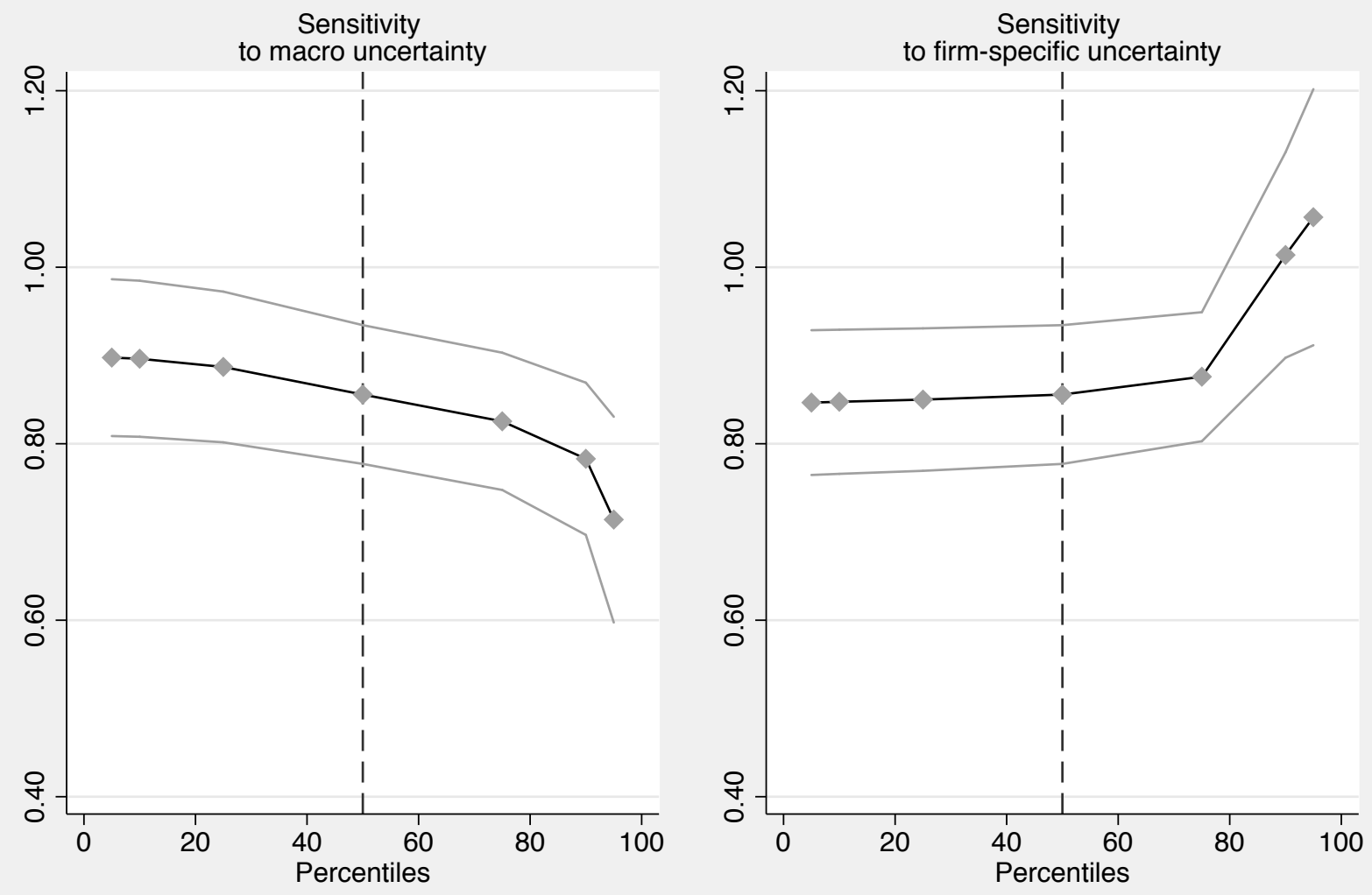

Figure 2: Sensitivity of marginal value of cash 


\section{Subsamples by Payout, using $\Delta \mathrm{C} 1$}

Low

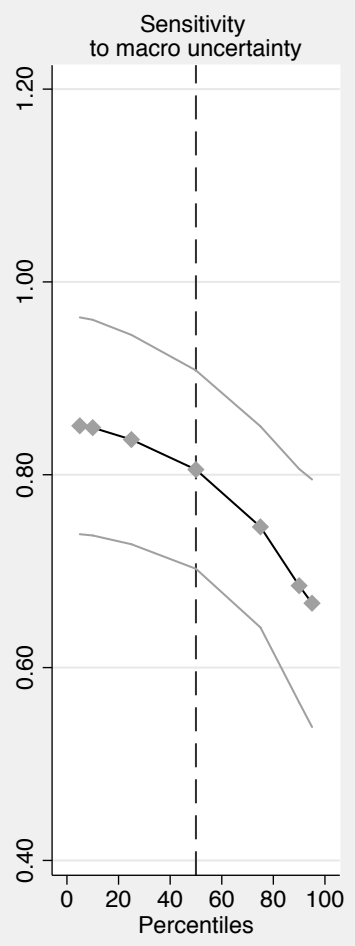

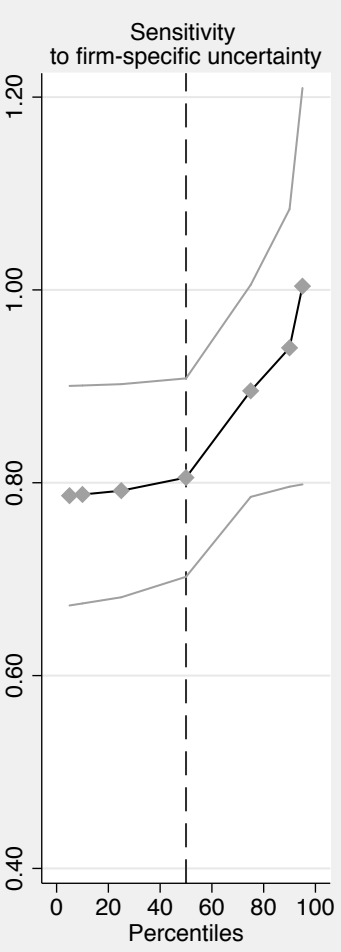

High
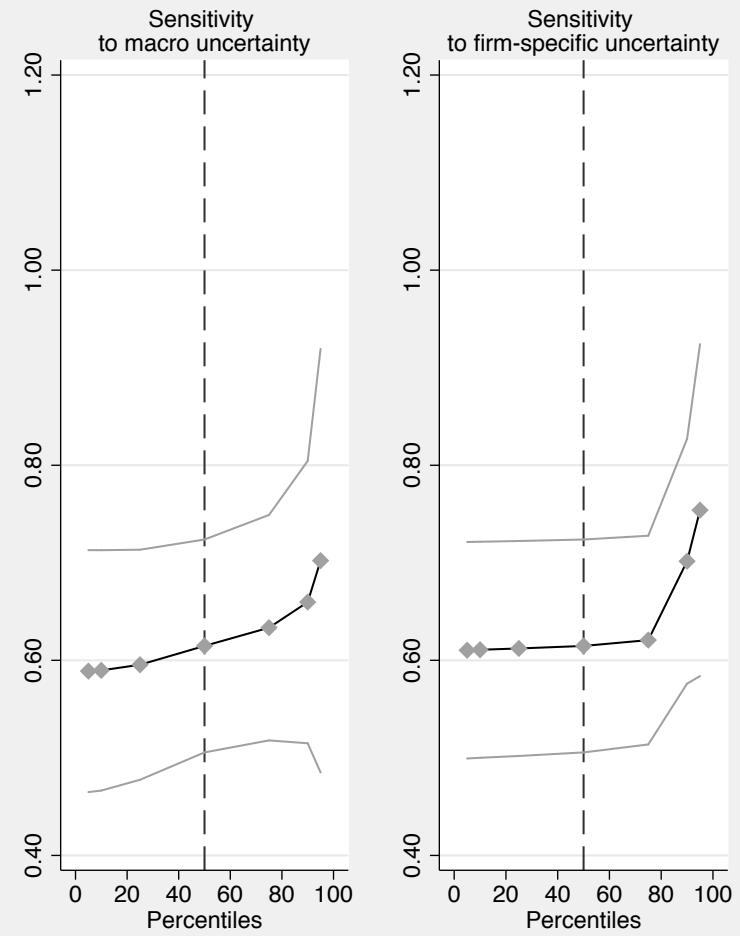

Figure 3: Sensitivity of marginal value of cash in subsamples 


\section{Subsamples by Payout, using $\Delta \mathrm{C} 3$}

Low

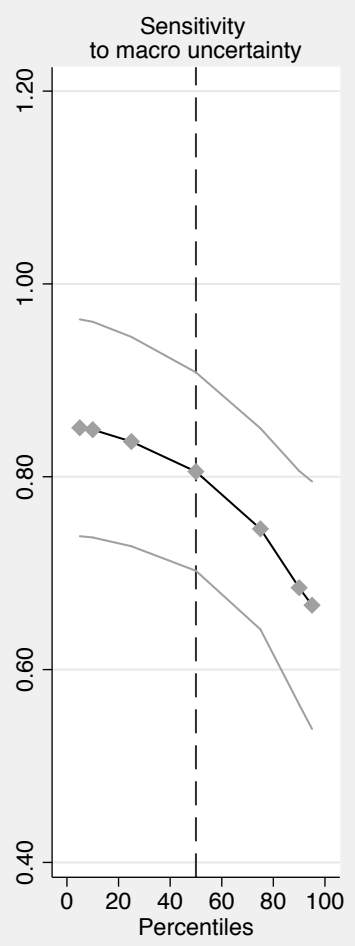

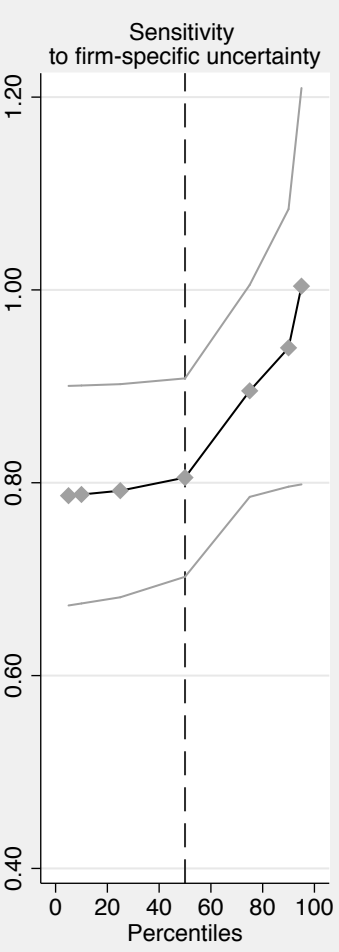

High
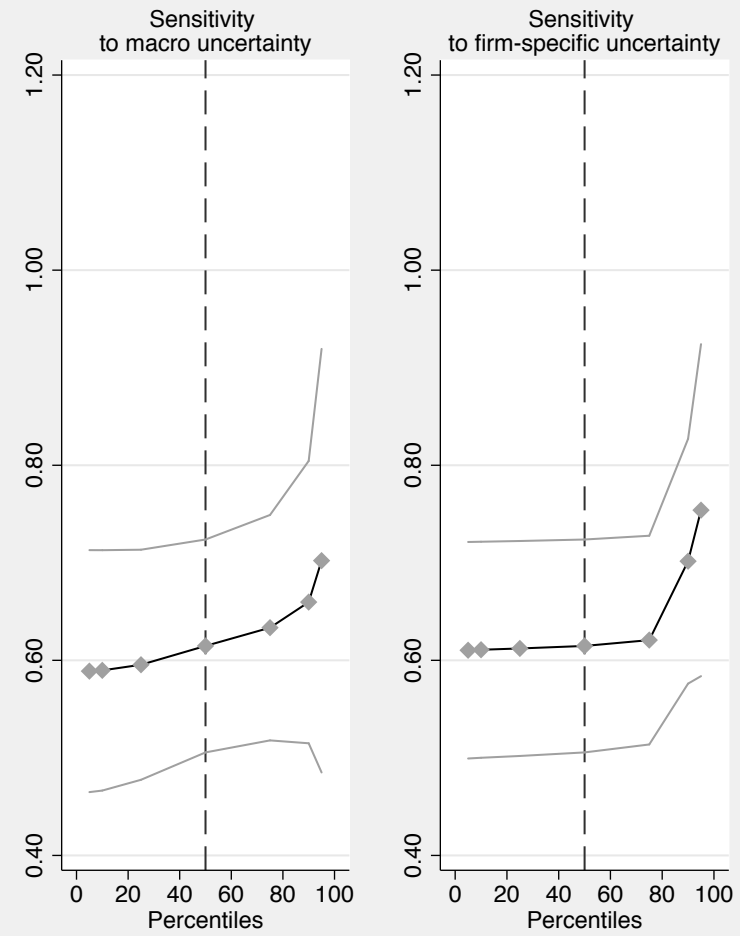

Figure 4: Sensitivity of marginal value of cash in subsamples 


\section{Subsamples by Size, using $\Delta \mathrm{C} 1$}

Low

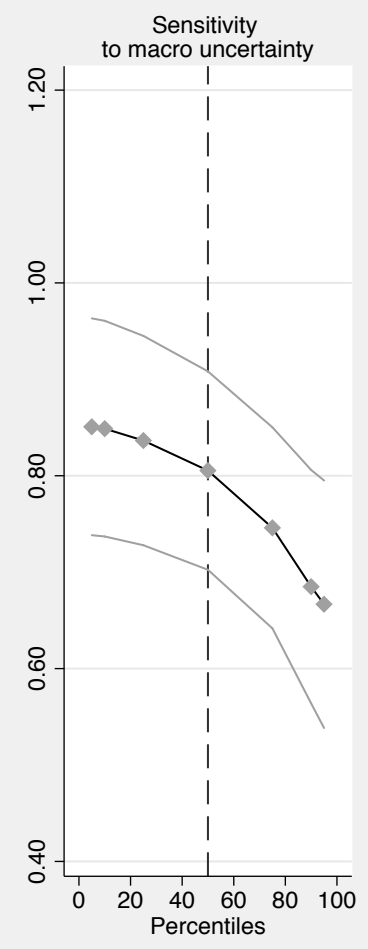

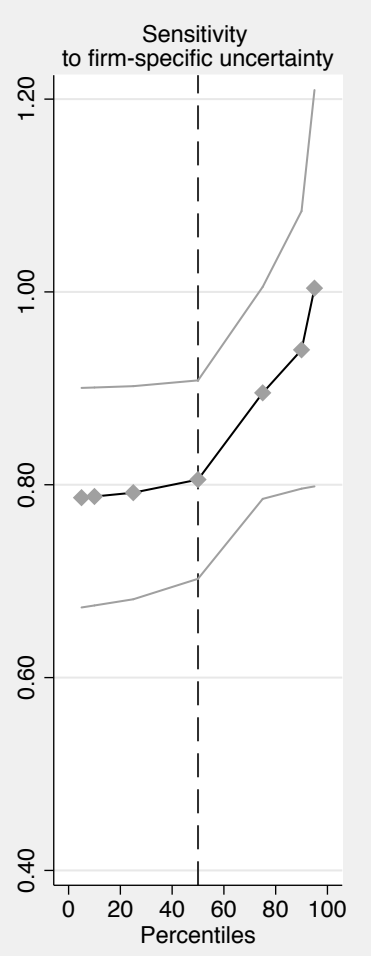

High

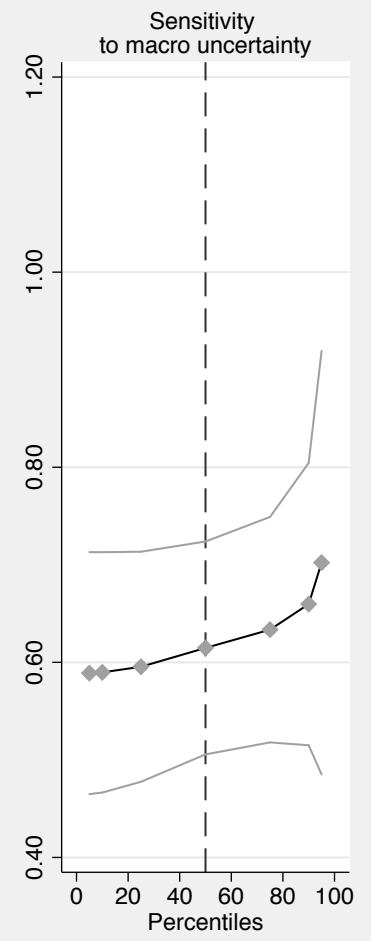

Figure 5: Sensitivity of marginal value of cash in subsamples 


\section{Subsamples by Size, using $\Delta \mathrm{C} 3$}

Low

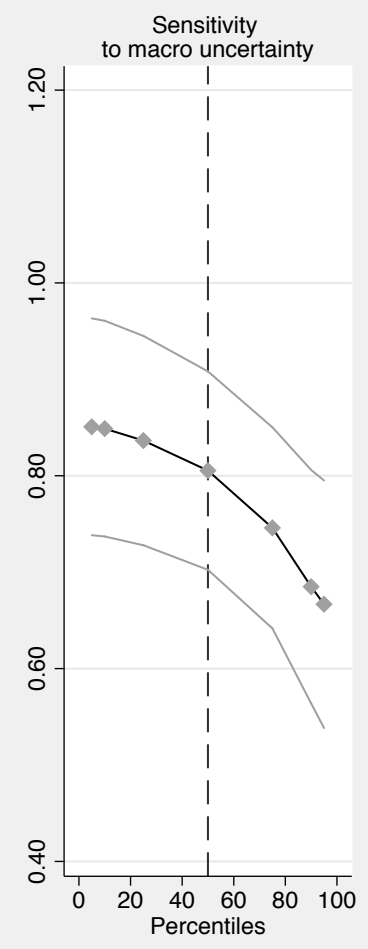

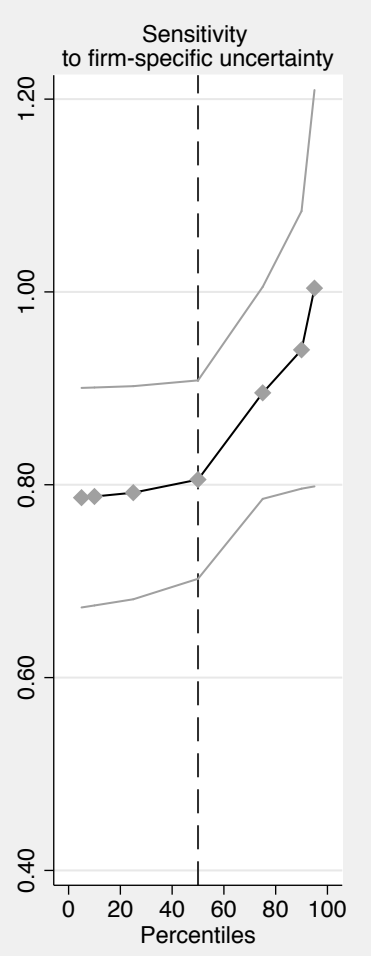

High

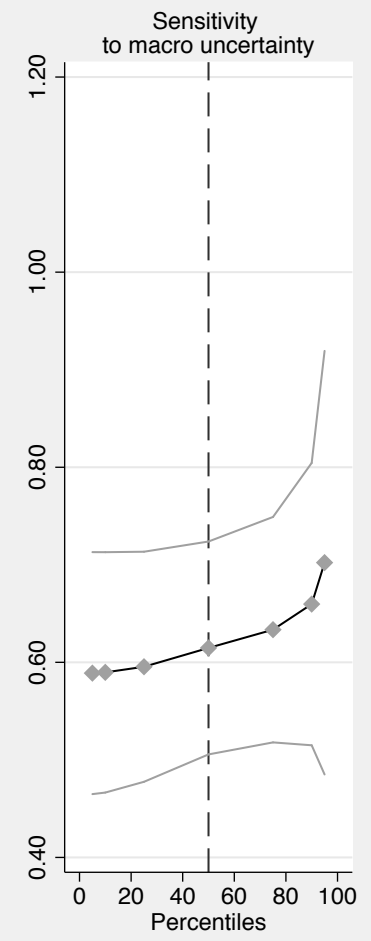

Figure 6: Sensitivity of marginal value of cash in subsamples 
Table 1: GARCH model estimates, 1962m3-2006m12

\begin{tabular}{lc}
\hline \hline & CPI Inflation \\
\hline Inflation $_{t-1}$ & $0.578^{* * *}$ \\
& $(15.907)$ \\
Constant & $0.001^{* * *}$ \\
& $(8.957)$ \\
\hline$A R C H(1)$ & $0.157^{* * *}$ \\
& $(3.484)$ \\
& $0.802^{* * *}$ \\
GARCH(1) & $(16.116)$ \\
& $0.000^{* *}$ \\
Constant & $(2.158)$ \\
\hline$t$ d.f. & $1.505^{* * *}$ \\
& $(4.091)$ \\
\hline log-likelihood & 2533.977 \\
Observations & 538 \\
\hline \hline
\end{tabular}

Notes: $t$ statistics in parentheses. ${ }^{*} p<0.10,{ }^{* *} p<0.05,{ }^{* * *} p<0.01$. 
Table 2: Descriptive Statistics, 1972-2006

This table provides summary statistics for the variables in our sample for firm-years of U.S. manufacturing firms over the period 1972-2006. ExcR is excess stock returns, $C$ is cash holdings, and $\Delta C 1, \Delta C 3$ are alternative measures of the unexpected change in cash holdings. $E$ is earnings before extraordinary items, $N A$ is total assets minus cash holdings, $R D$ is research and development expenses, $I$ is interest expense, $D$ is common dividends, $L$ is market leverage, and $N F$ is equity issuance net of repurchases plus debt issuance minus debt redemption. Payout is the payout ratio (dividends plus repurchases over earnings), and Sales is net sales. $\Delta X_{t}$ refers to the first difference $X_{t}-X_{t-1} . \sigma_{M}^{2}$ and $\sigma_{f}^{2}$ are time-varying proxies for macroeconomic and firm-specific uncertainty, respectively. $p 25, p 50, p 75$ are the quartiles of the measure, and $N$ is the number of firm-years for which data are available.

\begin{tabular}{lrrrrrrrr}
\hline \hline & mean & s.d. & $p 25$ & $p 50$ & $p 75$ & $N$ & min & max \\
\hline ExcR & -0.1071 & 0.6184 & -0.4520 & -0.1964 & 0.0947 & 60,981 & -1.5936 & 10.9868 \\
$C$ & 0.1949 & 0.2809 & 0.0391 & 0.1011 & 0.2379 & 60,697 & 0.0000 & 8.6200 \\
$\Delta C 1$ & 0.0092 & 0.1637 & -0.0346 & 0.0006 & 0.0422 & 60,981 & -2.1833 & 2.3645 \\
$\Delta C 3$ & 0.0008 & 0.1635 & -0.0433 & -0.0079 & 0.0338 & 60,981 & -2.1760 & 2.3541 \\
$\Delta E$ & 0.0142 & 0.3280 & -0.0435 & 0.0056 & 0.0482 & 60,981 & -4.1078 & 12.4543 \\
$\Delta N A$ & 0.0032 & 0.5728 & -0.1111 & 0.0223 & 0.1536 & 60,981 & -11.8435 & 5.0009 \\
$\Delta R D$ & -0.0008 & 0.0304 & 0.0000 & 0.0000 & 0.0013 & 60,981 & -1.0513 & 0.2172 \\
$\Delta I$ & -0.0041 & 0.0301 & -0.0064 & -0.0004 & 0.0030 & 60,981 & -0.7114 & 0.1887 \\
$\Delta D$ & 0.0001 & 0.0072 & 0.0000 & 0.0000 & 0.0008 & 60,981 & -0.1057 & 0.1150 \\
$L$ & 0.3040 & 0.2385 & 0.0998 & 0.2663 & 0.4695 & 60,981 & 0.0000 & 0.9856 \\
$N F$ & 0.0335 & 0.2756 & -0.0467 & 0.0000 & 0.0747 & 60,981 & -3.1673 & 3.1174 \\
Sales & 990.2795 & 2256.9440 & 47.1377 & 184.6376 & 755.2063 & 59,986 & 0.0000 & 30,523 \\
Payout & 0.2411 & 0.4854 & 0.0000 & 0.1024 & 0.3269 & 56,340 & -3.4313 & 6.5102 \\
$\sigma_{M}^{2}$ & 0.0056 & 0.0032 & 0.0031 & 0.0050 & 0.0071 & 60,981 & 0.0023 & 0.0154 \\
$\sigma_{f}^{2}$ & 0.0415 & 0.1001 & 0.0103 & 0.0199 & 0.0402 & 60,981 & 0.0000 & 6.7256 \\
\hline
\end{tabular}


Table 3: Estimates for full sample

\begin{tabular}{|c|c|c|c|c|}
\hline & $\begin{array}{c}(1) \\
\mathrm{dC} 1\end{array}$ & $\begin{array}{c}(2) \\
\mathrm{dC} 1\end{array}$ & $\begin{array}{c}(3) \\
\mathrm{dC} 3\end{array}$ & $\begin{array}{c}(4) \\
\mathrm{dC} 3\end{array}$ \\
\hline$\Delta C$ & $\begin{array}{l}1.2435^{* * *} \\
(23.4936)\end{array}$ & $\begin{array}{l}1.2531^{* * *} \\
(18.2530)\end{array}$ & $\begin{array}{l}1.2617^{* * *} \\
(22.9363)\end{array}$ & $\begin{array}{l}1.2670^{* * *} \\
(17.6525)\end{array}$ \\
\hline$\Delta E$ & $\begin{array}{l}0.2949^{* * *} \\
(16.5485)\end{array}$ & $\begin{array}{l}0.2928^{* * *} \\
(16.4515)\end{array}$ & $\begin{array}{l}0.3207^{* * *} \\
(18.1426)\end{array}$ & $\begin{array}{l}0.3187^{* * *} \\
(17.9634)\end{array}$ \\
\hline$\Delta N A$ & $\begin{array}{l}0.1414^{* * *} \\
(14.2882)\end{array}$ & $\begin{array}{l}0.1380^{* * *} \\
(13.9016)\end{array}$ & $\begin{array}{l}0.1448^{* * *} \\
(13.5374)\end{array}$ & $\begin{array}{l}0.1417^{* * *} \\
(13.2244)\end{array}$ \\
\hline$\Delta R D$ & $\begin{array}{c}-1.3631^{* * *} \\
(-6.6009)\end{array}$ & $\begin{array}{c}-1.3802^{* * *} \\
(-6.7001)\end{array}$ & $\begin{array}{c}-1.0634^{* * *} \\
(-4.5269)\end{array}$ & $\begin{array}{c}-1.0801^{* * *} \\
(-4.5891)\end{array}$ \\
\hline$\Delta I$ & $\begin{array}{c}-2.8297^{* * *} \\
(-22.5495)\end{array}$ & $\begin{array}{c}-2.8597^{* * *} \\
(-22.1824)\end{array}$ & $\begin{array}{c}-2.8227^{* * *} \\
(-20.7089)\end{array}$ & $\begin{array}{l}-2.8352^{* * *} \\
(-20.4223)\end{array}$ \\
\hline$\Delta D$ & $\begin{array}{c}1.1150^{* * *} \\
(3.7342)\end{array}$ & $\begin{array}{c}1.0670^{* * *} \\
(3.5203)\end{array}$ & $\begin{array}{c}0.9718^{* * *} \\
(3.1295)\end{array}$ & $\begin{array}{c}0.9591^{* * *} \\
(3.0588)\end{array}$ \\
\hline$C_{t-1}$ & $\begin{array}{l}0.1786^{* * *} \\
(11.6092)\end{array}$ & $\begin{array}{l}0.1712^{* * *} \\
(11.0541)\end{array}$ & $\begin{array}{l}0.1909^{* * *} \\
(12.3402)\end{array}$ & $\begin{array}{l}0.1829^{* * *} \\
(11.8054)\end{array}$ \\
\hline Lev & $\begin{array}{l}-1.0323^{* * *} \\
(-54.5933)\end{array}$ & $\begin{array}{l}-1.0464^{* * *} \\
(-54.5159)\end{array}$ & $\begin{array}{l}-1.0219^{* * *} \\
(-51.2087)\end{array}$ & $\begin{array}{c}-1.0291^{* * *} \\
(-51.2529)\end{array}$ \\
\hline$N F$ & $\begin{array}{c}0.1636^{* * *} \\
(8.9128)\end{array}$ & $\begin{array}{c}0.1640^{* * *} \\
(8.9325)\end{array}$ & $\begin{array}{c}0.1344^{* * *} \\
(6.9613)\end{array}$ & $\begin{array}{c}0.1350^{* * *} \\
(7.0098)\end{array}$ \\
\hline$C_{t-1} \times \Delta C$ & $\begin{array}{c}-0.2292^{* * *} \\
(-4.4705)\end{array}$ & $\begin{array}{c}-0.2492^{* * *} \\
(-4.9924)\end{array}$ & $\begin{array}{c}-0.2657^{* * *} \\
(-5.4859)\end{array}$ & $\begin{array}{c}-0.2850^{* * *} \\
(-5.9077)\end{array}$ \\
\hline Lev $\times \Delta C$ & $\begin{array}{c}-1.2985^{* * *} \\
(-14.3134)\end{array}$ & $\begin{array}{c}-1.2412^{* * *} \\
(-13.7811)\end{array}$ & $\begin{array}{c}-1.2833^{* * *} \\
(-13.6976)\end{array}$ & $\begin{array}{l}-1.2174^{* * *} \\
(-12.9705)\end{array}$ \\
\hline$\sigma_{M}^{2}$ & & $\begin{array}{l}-7.3816^{* * *} \\
(-11.7207)\end{array}$ & & $\begin{array}{c}-7.3623^{* * *} \\
(-11.3681)\end{array}$ \\
\hline$\sigma_{f}^{2}$ & & $\begin{array}{c}0.0306^{*} \\
(1.7237)\end{array}$ & & $\begin{array}{c}0.0288 \\
(1.3266)\end{array}$ \\
\hline$\sigma_{M}^{2} \times \Delta C$ & & $\begin{array}{c}-16.3407^{* * *} \\
(-2.8248)\end{array}$ & & $\begin{array}{c}-16.0717^{* * *} \\
(-2.7499)\end{array}$ \\
\hline$\sigma_{f}^{2} \times \Delta C$ & & $\begin{array}{l}0.3363^{* *} \\
(2.2594) \\
\end{array}$ & & $\begin{array}{l}0.4464^{* *} \\
(2.4521)\end{array}$ \\
\hline$R^{2}$ & 0.189 & 0.190 & 0.194 & 0.195 \\
\hline Marg.value & 0.891 & 0.841 & 0.904 & 0.856 \\
\hline std.err. & 0.035 & 0.039 & 0.036 & 0.040 \\
\hline $\mathrm{N}$ & 79,957 & 77,608 & 70,649 & 69,534 \\
\hline
\end{tabular}


Table 4: Subsamples by Payout, using $\Delta C 1$

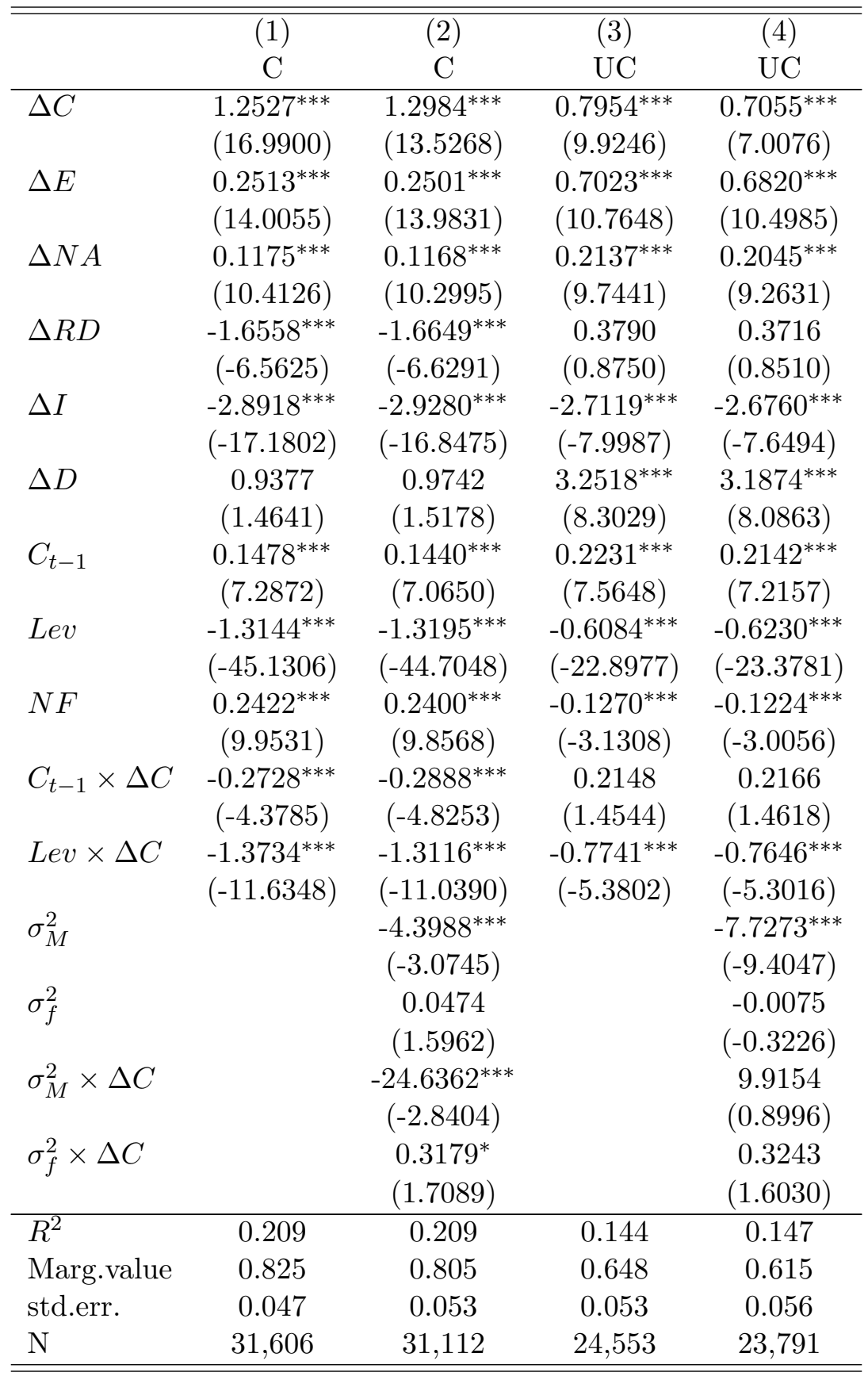

$t$ statistics in parentheses

${ }^{*} p<0.10,{ }^{* *} p<0.05,{ }^{* * *} p<0.01$ 
Table 5: Subsamples by Payout, using $\Delta C 3$

\begin{tabular}{|c|c|c|c|c|}
\hline & (1) & (2) & (3) & (4) \\
\hline & $\mathrm{C}$ & $\mathrm{C}$ & $\mathrm{UC}$ & $\mathrm{UC}$ \\
\hline$\Delta C$ & $\begin{array}{l}1.2807^{* * *} \\
(16.1188)\end{array}$ & $\begin{array}{l}1.3284^{* * *} \\
(13.1170)\end{array}$ & $\begin{array}{c}0.7880^{* * *} \\
(9.6149)\end{array}$ & $\begin{array}{c}0.7188^{* * *} \\
(6.9485)\end{array}$ \\
\hline$\Delta E$ & $\begin{array}{l}0.2711^{* * *} \\
(15.2203)\end{array}$ & $\begin{array}{l}0.2694^{* * *} \\
(15.1090)\end{array}$ & $\begin{array}{l}0.7009^{* * *} \\
(10.1876)\end{array}$ & $\begin{array}{c}0.6800^{* * *} \\
(9.9558)\end{array}$ \\
\hline$\Delta N A$ & $\begin{array}{c}0.1189^{* * *} \\
(9.8625)\end{array}$ & $\begin{array}{c}0.1186^{* * *} \\
(9.8073)\end{array}$ & $\begin{array}{c}0.2150^{* * *} \\
(9.2780)\end{array}$ & $\begin{array}{c}0.2064^{* * *} \\
(8.8594)\end{array}$ \\
\hline$\Delta R D$ & $\begin{array}{c}-1.4106^{* * *} \\
(-4.8608)\end{array}$ & $\begin{array}{c}-1.4164^{* * *} \\
(-4.8861)\end{array}$ & $\begin{array}{c}0.3421 \\
(0.7706)\end{array}$ & $\begin{array}{c}0.3239 \\
(0.7266)\end{array}$ \\
\hline$\Delta I$ & $\begin{array}{l}-2.8299^{* * *} \\
(-15.5805)\end{array}$ & $\begin{array}{l}-2.8615^{* * *} \\
(-15.3418)\end{array}$ & $\begin{array}{c}-2.7262^{* * *} \\
(-7.8710)\end{array}$ & $\begin{array}{c}-2.7056^{* * *} \\
(-7.6253)\end{array}$ \\
\hline$\Delta D$ & $\begin{array}{c}0.9221 \\
(1.3649)\end{array}$ & $\begin{array}{c}0.9860 \\
(1.4586)\end{array}$ & $\begin{array}{c}3.1163^{* * *} \\
(7.7795)\end{array}$ & $\begin{array}{c}3.0328^{* * *} \\
(7.5355)\end{array}$ \\
\hline$C_{t-1}$ & $\begin{array}{c}0.1574^{* * *} \\
(7.7298)\end{array}$ & $\begin{array}{c}0.1537^{* * *} \\
(7.5452)\end{array}$ & $\begin{array}{c}0.2267^{* * *} \\
(7.1756)\end{array}$ & $\begin{array}{c}0.2194^{* * *} \\
(6.9270)\end{array}$ \\
\hline Lev & $\begin{array}{l}-1.3212^{* * *} \\
(-41.9613)\end{array}$ & $\begin{array}{c}-1.3226^{* * *} \\
(-41.7603)\end{array}$ & $\begin{array}{l}-0.6225^{* * *} \\
(-22.6179)\end{array}$ & $\begin{array}{l}-0.6327^{* * *} \\
(-23.1799)\end{array}$ \\
\hline$N F$ & $\begin{array}{c}0.2139^{* * *} \\
(8.2352)\end{array}$ & $\begin{array}{c}0.2113^{* * *} \\
(8.1508)\end{array}$ & $\begin{array}{c}-0.1305^{* * *} \\
(-3.0559)\end{array}$ & $\begin{array}{c}-0.1261^{* * *} \\
(-2.9448)\end{array}$ \\
\hline$C_{t-1} \times \Delta C$ & $\begin{array}{c}-0.3443^{* * *} \\
(-5.4992)\end{array}$ & $\begin{array}{c}-0.3616^{* * *} \\
(-5.8367)\end{array}$ & $\begin{array}{c}0.2189 \\
(1.4304)\end{array}$ & $\begin{array}{c}0.2217 \\
(1.4519)\end{array}$ \\
\hline Lev $\times \Delta C$ & $\begin{array}{c}-1.3473^{* * *} \\
(-10.6243)\end{array}$ & $\begin{array}{c}-1.2774^{* * *} \\
(-10.0115)\end{array}$ & $\begin{array}{c}-0.7647^{* * *} \\
(-5.1861)\end{array}$ & $\begin{array}{c}-0.7507^{* * *} \\
(-5.0349)\end{array}$ \\
\hline$\sigma_{M}^{2}$ & & $\begin{array}{c}-4.3730^{* * *} \\
(-2.8621)\end{array}$ & & $\begin{array}{c}-7.7347^{* * *} \\
(-9.1642)\end{array}$ \\
\hline$\sigma_{f}^{2}$ & & $\begin{array}{c}0.0519 \\
(1.4395)\end{array}$ & & $\begin{array}{c}0.0011 \\
(0.0404)\end{array}$ \\
\hline$\sigma_{M}^{2} \times \Delta C$ & & $\begin{array}{c}-25.1155^{* * *} \\
(-2.8933)\end{array}$ & & $\begin{array}{c}8.3553 \\
(0.7674)\end{array}$ \\
\hline$\sigma_{f}^{2} \times \Delta C$ & & $\begin{array}{c}0.4119^{*} \\
(1.7173)\end{array}$ & & $\begin{array}{c}0.2034 \\
(0.9102)\end{array}$ \\
\hline$R^{2}$ & 0.217 & 0.218 & 0.144 & 0.147 \\
\hline Marg.value & 0.836 & 0.818 & 0.643 & 0.622 \\
\hline std.err. & 0.049 & 0.056 & 0.054 & 0.057 \\
\hline $\mathrm{N}$ & 26,455 & 26,255 & 23,057 & 22,669 \\
\hline
\end{tabular}

$t$ statistics in parentheses

${ }^{*} p<0.10,{ }^{* *} p<0.05,{ }^{* * *} p<0.01$ 
Table 6: Subsamples by Size, using $\Delta C 1$

\begin{tabular}{|c|c|c|c|c|}
\hline & (1) & (2) & (3) & (4) \\
\hline & $\mathrm{C}$ & $\mathrm{C}$ & $\mathrm{UC}$ & $\mathrm{UC}$ \\
\hline$\Delta C$ & $\begin{array}{l}0.9992^{* * *} \\
(11.2752)\end{array}$ & $\begin{array}{c}1.0792^{* * *} \\
(8.5999)\end{array}$ & $\begin{array}{l}1.3611^{* * *} \\
(13.1132)\end{array}$ & $\begin{array}{c}1.1764^{* * *} \\
(9.6742)\end{array}$ \\
\hline$\Delta E$ & $\begin{array}{c}0.2447^{* * *} \\
(8.6782)\end{array}$ & $\begin{array}{c}0.2426^{* * *} \\
(8.6296)\end{array}$ & $\begin{array}{l}0.3325^{* * *} \\
(12.5603)\end{array}$ & $\begin{array}{l}0.3296^{* * *} \\
(12.4707)\end{array}$ \\
\hline$\Delta N A$ & $\begin{array}{c}0.1028^{* * *} \\
(4.2841)\end{array}$ & $\begin{array}{c}0.1047^{* * *} \\
(4.3563)\end{array}$ & $\begin{array}{c}0.1468^{* * *} \\
(9.2490)\end{array}$ & $\begin{array}{c}0.1422^{* * *} \\
(8.9643)\end{array}$ \\
\hline$\Delta R D$ & $\begin{array}{c}-1.9985^{* * *} \\
(-7.1549)\end{array}$ & $\begin{array}{c}-2.0098^{* * *} \\
(-7.2247)\end{array}$ & $\begin{array}{c}-0.4427 \\
(-0.9850)\end{array}$ & $\begin{array}{c}-0.3509 \\
(-0.9079)\end{array}$ \\
\hline$\Delta I$ & $\begin{array}{c}-2.6014^{* * *} \\
(-9.4050)\end{array}$ & $\begin{array}{c}-2.6690^{* * *} \\
(-9.3765)\end{array}$ & $\begin{array}{c}-2.6946^{* * *} \\
(-13.5192)\end{array}$ & $\begin{array}{l}-2.6782^{* * *} \\
(-13.1003)\end{array}$ \\
\hline$\Delta D$ & $\begin{array}{c}2.8354^{* * *} \\
(3.2853)\end{array}$ & $\begin{array}{c}2.7629^{* * *} \\
(3.1284)\end{array}$ & $\begin{array}{l}1.0737^{* *} \\
(2.3247)\end{array}$ & $\begin{array}{l}1.0320^{* *} \\
(2.2229)\end{array}$ \\
\hline$C_{t-1}$ & $\begin{array}{c}0.1018^{* * *} \\
(3.7684)\end{array}$ & $\begin{array}{c}0.0956^{* * *} \\
(3.5151)\end{array}$ & $\begin{array}{l}0.2737^{* * *} \\
(10.5127)\end{array}$ & $\begin{array}{c}0.2656^{* * *} \\
(9.9065)\end{array}$ \\
\hline Lev & $\begin{array}{l}-1.4533^{* * *} \\
(-31.1632)\end{array}$ & $\begin{array}{l}-1.4603^{* * *} \\
(-30.7993)\end{array}$ & $\begin{array}{l}-0.8420^{* * *} \\
(-31.7172)\end{array}$ & $\begin{array}{c}-0.8535^{* * *} \\
(-31.6641)\end{array}$ \\
\hline$N F$ & $\begin{array}{l}0.5289^{* * *} \\
(11.6393)\end{array}$ & $\begin{array}{l}0.5257^{* * *} \\
(11.4797)\end{array}$ & $\begin{array}{c}-0.0195 \\
(-0.7086)\end{array}$ & $\begin{array}{c}-0.0184 \\
(-0.6747)\end{array}$ \\
\hline$C_{t-1} \times \Delta C$ & $\begin{array}{c}-0.2911^{* * *} \\
(-3.7084)\end{array}$ & $\begin{array}{c}-0.3066^{* * *} \\
(-4.0502)\end{array}$ & $\begin{array}{c}-0.1897^{* *} \\
(-2.5343)\end{array}$ & $\begin{array}{c}-0.1674^{* *} \\
(-2.1999)\end{array}$ \\
\hline$L e v \times \Delta C$ & $\begin{array}{c}-1.1826^{* * *} \\
(-7.3793)\end{array}$ & $\begin{array}{c}-1.1480^{* * *} \\
(-7.1979)\end{array}$ & $\begin{array}{c}-1.3202^{* * *} \\
(-7.0555)\end{array}$ & $\begin{array}{c}-1.2834^{* * *} \\
(-7.1011)\end{array}$ \\
\hline$\sigma_{M}^{2}$ & & $\begin{array}{c}-7.9939^{* * *} \\
(-3.9337)\end{array}$ & & $\begin{array}{c}-5.7788^{* * *} \\
(-7.3901)\end{array}$ \\
\hline$\sigma_{f}^{2}$ & & $\begin{array}{c}0.0368 \\
(0.8482)\end{array}$ & & $\begin{array}{c}0.0277 \\
(0.9843)\end{array}$ \\
\hline$\sigma_{M}^{2} \times \Delta C$ & & $\begin{array}{c}-27.8206^{* *} \\
(-2.4236)\end{array}$ & & $\begin{array}{l}10.4105 \\
(1.0324)\end{array}$ \\
\hline$\sigma_{f}^{2} \times \Delta C$ & & $\begin{array}{c}0.2528 \\
(1.1277)\end{array}$ & & $\begin{array}{l}1.0181^{* *} \\
(2.2927)\end{array}$ \\
\hline$R^{2}$ & 0.195 & 0.196 & 0.190 & 0.193 \\
\hline Marg.value & 0.776 & 0.755 & 0.967 & 0.859 \\
\hline std.err. & 0.067 & 0.070 & 0.062 & 0.060 \\
\hline $\mathrm{N}$ & 17,264 & 16,883 & 28,890 & 27,900 \\
\hline
\end{tabular}


Table 7: Subsamples by Size, using $\Delta C 3$

\begin{tabular}{|c|c|c|c|c|}
\hline & (1) & (2) & (3) & (4) \\
\hline & $\mathrm{C}$ & $\mathrm{C}$ & $\mathrm{UC}$ & $\mathrm{UC}$ \\
\hline$\Delta C$ & $\begin{array}{l}1.0854^{* * *} \\
(11.4510)\end{array}$ & $\begin{array}{c}1.1847^{* * *} \\
(8.9954)\end{array}$ & $\begin{array}{l}1.3102^{* * *} \\
(13.2624)\end{array}$ & $\begin{array}{c}1.1914^{* * *} \\
(9.6718)\end{array}$ \\
\hline$\Delta E$ & $\begin{array}{c}0.2410^{* * *} \\
(7.8843)\end{array}$ & $\begin{array}{c}0.2405^{* * *} \\
(7.8460)\end{array}$ & $\begin{array}{l}0.3354^{* * *} \\
(12.1812)\end{array}$ & $\begin{array}{l}0.3331^{* * *} \\
(12.0991)\end{array}$ \\
\hline$\Delta N A$ & $\begin{array}{c}0.1161^{* * *} \\
(4.1802)\end{array}$ & $\begin{array}{c}0.1186^{* * *} \\
(4.2620)\end{array}$ & $\begin{array}{c}0.1450^{* * *} \\
(8.8502)\end{array}$ & $\begin{array}{c}0.1410^{* * *} \\
(8.6224)\end{array}$ \\
\hline$\Delta R D$ & $\begin{array}{c}-1.7812^{* * *} \\
(-5.0176)\end{array}$ & $\begin{array}{c}-1.8012^{* * *} \\
(-5.0727)\end{array}$ & $\begin{array}{c}-0.0057 \\
(-0.0171)\end{array}$ & $\begin{array}{c}-0.0167 \\
(-0.0507)\end{array}$ \\
\hline$\Delta I$ & $\begin{array}{c}-2.8098^{* * *} \\
(-8.5560)\end{array}$ & $\begin{array}{c}-2.8439^{* * *} \\
(-8.4796)\end{array}$ & $\begin{array}{c}-2.7580^{* * *} \\
(-13.5558)\end{array}$ & $\begin{array}{c}-2.7378^{* * *} \\
(-13.1382)\end{array}$ \\
\hline$\Delta D$ & $\begin{array}{c}2.6568^{* * *} \\
(2.9471)\end{array}$ & $\begin{array}{c}2.6095^{* * *} \\
(2.8463)\end{array}$ & $\begin{array}{c}0.7646 \\
(1.5909)\end{array}$ & $\begin{array}{c}0.7764 \\
(1.6059)\end{array}$ \\
\hline$C_{t-1}$ & $\begin{array}{c}0.1147^{* * *} \\
(3.9452)\end{array}$ & $\begin{array}{c}0.1071^{* * *} \\
(3.6688)\end{array}$ & $\begin{array}{l}0.2745^{* * *} \\
(10.3611)\end{array}$ & $\begin{array}{l}0.2672^{* * *} \\
(10.0302)\end{array}$ \\
\hline Lev & $\begin{array}{c}-1.4608^{* * *} \\
(-27.8567)\end{array}$ & $\begin{array}{c}-1.4643^{* * *} \\
(-27.6505)\end{array}$ & $\begin{array}{l}-0.8541^{* * *} \\
(-30.8327)\end{array}$ & $\begin{array}{c}-0.8584^{* * *} \\
(-30.9050)\end{array}$ \\
\hline$N F$ & $\begin{array}{c}0.5022^{* * *} \\
(9.8460)\end{array}$ & $\begin{array}{c}0.4991^{* * *} \\
(9.7303)\end{array}$ & $\begin{array}{c}-0.0235 \\
(-0.8410)\end{array}$ & $\begin{array}{c}-0.0216 \\
(-0.7711)\end{array}$ \\
\hline$C_{t-1} \times \Delta C$ & $\begin{array}{c}-0.3964^{* * *} \\
(-5.5357)\end{array}$ & $\begin{array}{c}-0.4122^{* * *} \\
(-5.6890)\end{array}$ & $\begin{array}{l}-0.1840^{* *} \\
(-2.3087)\end{array}$ & $\begin{array}{l}-0.1713^{* *} \\
(-2.1425)\end{array}$ \\
\hline Lev $\times \Delta C$ & $\begin{array}{c}-1.2382^{* * *} \\
(-7.2790)\end{array}$ & $\begin{array}{c}-1.1918^{* * *} \\
(-6.9743)\end{array}$ & $\begin{array}{c}-1.2682^{* * *} \\
(-6.7410)\end{array}$ & $\begin{array}{c}-1.2451^{* * *} \\
(-6.7256)\end{array}$ \\
\hline$\sigma_{M}^{2}$ & & $\begin{array}{c}-7.5264^{* * *} \\
(-3.3570)\end{array}$ & & $\begin{array}{c}-5.4637^{* * *} \\
(-6.8308)\end{array}$ \\
\hline$\sigma_{f}^{2}$ & & $\begin{array}{c}-0.0281 \\
(-0.5686)\end{array}$ & & $\begin{array}{c}0.0540 \\
(1.5393)\end{array}$ \\
\hline$\sigma_{M}^{2} \times \Delta C$ & & $\begin{array}{c}-32.4651^{* * *} \\
(-2.7444)\end{array}$ & & $\begin{array}{c}7.5228 \\
(0.7693)\end{array}$ \\
\hline$\sigma_{f}^{2} \times \Delta C$ & & $\begin{array}{c}0.3316 \\
(1.1588)\end{array}$ & & $\begin{array}{l}0.8857^{*} \\
(1.6772)\end{array}$ \\
\hline$R^{2}$ & 0.202 & 0.203 & 0.189 & 0.190 \\
\hline Marg.value & 0.836 & 0.809 & 0.932 & 0.871 \\
\hline std.err. & 0.071 & 0.076 & 0.057 & 0.061 \\
\hline $\mathrm{N}$ & 13,732 & 13,574 & 27,005 & 26,457 \\
\hline
\end{tabular}

$t$ statistics in parentheses

${ }^{*} p<0.10,{ }^{* *} p<0.05,{ }^{* * *} p<0.01$ 